\title{
Enough Is [Never?] Enough
}

\section{Carol Iannone}

Are these the times that try men's souls? It seems so. Every day brings its complement of assaults and batteries upon our country, our culture, our foundations, our institutions, our monuments, our heroes, our symbols, our history, our "whiteness."

Some see a political crisis, some cultural, some constitutional, economic, legal, educational, even aesthetic, but really all aspects are involved. Pull any one thread and you will find it connected to the others. The assault from the progressive left is truly totalitarian in intention and is having a malignantly fluorescing apotheosis at the present time, punitive and even violent.

A country that had prided itself as premised on God given natural rights and equality under the law, and not on blood, soil, race, or ethnicity, is now saturated in identity politics, group entitlements, racial animosity, and victimhood.

Far from being our strength, as the slogan had it for so many years, diversity is proving to be an undoing of basic American ideals. In the mandate to make every corner of society “look like America,” that is, to reflect everywhere proportional representation of racial and ethnic groups as presently constituted (and a proliferating panoply of other groups added on), it has proved corrosive and divisive, and so far from enhancing education, it has diminished it.

Lately, with the emergence of the extent and specificity to which critical race theory indoctrination and training has advanced in schools, corporations, and government, as Christopher Rufo of the Manhattan Institute has brought to light-the brightest line is now that between white and non-white, with whites denigrated and villainized, subject to discrimination and harassment as a matter of institutional, corporate, and government policy. Reason, objectivity, merit, precision, hard work, are being called "white culture" and dismissed as oppressive. Critical race theory demonizes white people for the immutable

Carol lannone is editor-at-large of Academic Questions, 420 Madison Avenue, 7th Floor, New York, NY 10017; iannone@nas.org. 
characteristic of skin color, and even children are tutored to feel shame and guilt at their "white privilege," that is, being born white and continuing to exist.

The liberal arts and even STEM subjects have been dumbed down, diminished, and in some cases destroyed. Yale no longer requires English majors to read Shakespeare, Milton, Chaucer, Donne, Wordsworth. Princeton no longer requires Greek and Latin even for classics majors. The great works of the past are being replaced with more modern selections based on their appeal to the so called marginalized. A huge diversity bureaucracy has mushroomed throughout higher education and, recently, diversity itself has become an academic subject, as Heather Mac Donald details. If aggressive hiring of faculty who are trained in diversity continues, the great legacy of the classic liberal arts subjects might be lost altogether. No, we're not at the point in Fahrenheit 451 where senior people adopt young acolytes to whom to transmit by word of mouth the great books that have all been burnt by the reigning tyranny, but the analogy does come to mind.

Recently, students at Ohio's Bowling Green State University succeeded in having the name of legendary film actress Lillian Gish removed from the campus theatre due to her role in the 1915 silent film The Birth of a Nation which, though a landmark in screen history, glorifies the Klan. Gish's work in Hollywood began in the early days of film in 1912 and continued until 1987. A large group of celebrated performers, including James Earl Jones and Helen Mirren, have written an open letter asking that the totality of her career be considered, as well as the variety of roles she played, and not just one movie.

Learning to judge things in their totality, not only whole careers but individual works of art, the willingness to enter imaginative worlds, grant the artist his givens, suspend disbelief at least temporarily, is necessary in approaching creative work, and yet it appears to be lost on the next generation of artists, critics, and even performers, who judge everything in immediate political and racial terms. Black students at the Julliard Drama Division professed themselves "utterly broken" at a workshop-earnestly intended to further diversity awareness at the school-in which a clip portraying a slave auction from the popular 1977 miniseries Roots was shown, Heather Mac Donald reports. The love of theatre itself, the sense of being part of an honored craft, a great tradition, a devoted brotherhood, seems to have disappeared. Julliard's minority students, who number half the student body, object to having to study the European dramatic tradition of mainly white playwrights and believe they are entitled 
to bring their race-consciousness into whatever role they are cast. Not only do these students show an inability to enter imaginatively into and apprehend the life of art, some minority students at Julliard don't even understand the discipline needed to be a performer and feel they should not be penalized for missing or being late for class. As Mac Donald writes, they believe that “Juilliard's self-described 'rigorous' class schedule is 'deeply rooted in capitalist and white supremacist hegemony."”

Presidential executive orders are one of the ways that group equality, or "equity," has been made the de facto law of the land in spite of the Constitution and the Civil Rights Act of 1964. They go beyond their immediate application to the federal workforce because of the numerous private entities that have dealings with the federal government. It started with LBJ's Executive Order 11246 of 1965, aggressively executed and expanded in the Nixon Administration by Lawrence Silberman, Undersecretary of Labor in George Schultz's Labor Department, as I explained in my Introduction to Summer 2020. (Also during the Nixon years, quotas evidently made inroads into faculty hiring in the Ivy League thanks to J. Stanley Pottinger, who served as Director of the Office of Civil Rights in the Department of Health, Education, and Welfare. Pottinger was dating Gloria Steinem at the time and thought to increase his standing with her by becoming an affirmative action enforcer, according to the feminist cable mini-series Mrs. America, made in honor of the one-hundredth anniversary of the Nineteenth Amendment.)

Since then, affirmative action has been expanded by additional EOs (one under President Clinton may have been the first time that an ethnic group, Hispanic, was specifically named). Obama issued several, cited by Biden in his own Executive Order 14035 on Diversity, Equity, Inclusion, and Accessibility in the Federal Workforce, reprinted in this issue, slightly edited for brevity. This EO is perhaps the most expansive articulation of the new "woke" dispensation, mandating training effectively based on critical race theory throughout the federal workforce, as well as numerous other measures to increase "equity."

Along the way, the original civil rights language of negative rights, prohibiting discrimination based on race, sex, etc., slipped into positive rights, naming specific groups and specifically demanding "data-driven" efforts at their "inclusion." Along the way too, the rationale for diversity changed; the ecstatic dimension remains but the need to compensate for presumed past discrimination, specifically prohibited in Bakke, is now the major part. We must 
address "systemic and institutional racism and bias," including "implicit and unconscious bias," reads Biden's EO, toward the "undeserved communities" that "have been systematically denied a full opportunity to participate in aspects of economic, social, and civic life."

To my knowledge the Supreme Court has never directly addressed the question of executive orders and Lawrence Silberman's contention, soon regretted, that they can go beyond the scope of duly passed congressional legislation. The SC has accepted diversity, that is, representation of the different color groups that were developing through mass immigration as a compelling state interest and, in the context of college admissions, supposedly carrying educational benefits. Although it was theoretically meant to be subject to strict scrutiny, it never was in any substantial way, as explained in A Dubious Expediency: How Race Preferences Damage Higher Education (2021), and has expanded into virtual group entitlements for often less qualified minorities.

In Biden's EO, the list of “underserved communities of color" has grown beyond the minorities named in the census to "Black and African American, Hispanic and Latino, Native American, Alaska Native and Indigenous, Asian American, Native Hawaiian and Pacific Islander, Middle Eastern, and North African persons.” The Trump Administration had turned back an effort by lobbyists to add another vast pan-ethnic category to the census, people from the “Middle East or North Africa." Biden has added them to his list, not as one category, but as two separate categories of additional "underserved communities of color."

The "underserved" also includes a lengthy list of other categories, some familiar from the Civil Rights Act, and some relatively new, such as pregnant “persons" and people with limited English proficiency.

Biden's EOs have vacated Trump's Executive Order 13950, on Combatting Race and Sex Stereotyping, also reproduced in this issue, to prohibit critical race theory-inspired training in the federal workforce. Read Biden's EO in this issue and tell me if you don't see in every line the eclipse of the Republic we were supposed to “keep,” in Benjamin Franklin's word.

The activists have seized their chance. To hell with the meticulous detailed explanations for group disparities made by Thomas Sowell, Amy Wax, Lawrence Mead, Charles Murray, and Heather Mac Donald, and all that about bourgeois virtues, individual initiative, the problem of father absence, and the 
three simple rules to avoid poverty. Let's go straight for outright redistribution and massive government engineered equality of result.

The whole demand for equality or equity actually derives from America's own foundational premises, although it is a distortion of them. It is the reason critical theory is being granted any standing at all, as it now advances to the next step, seeking to upend the legal system entirely, and its whole basis in individual behavior, accountability, innocence, and guilt, through lawsuits challenging the legal system itself.

In this context, critical activists are maintaining that racism is so intrinsic to the American system “that you don't have to think about it anymore and you can have racism without racists at this point," says Robert Westley, a Tulane University law professor who specializes in critical race theory and reparations. "Treating people with dissimilar histories equally, where some have been historically oppressed, can lead to unjust results and outcomes, thereby requiring a focus on results and outcomes, not on blind process, with the goal being equal economic opportunity and equity.”

Critical race theory thus "challenges the very legitimacy of the legal system in which these lawsuits are situated," as another theorist proponent expounds.

This may sound like sawing off the branch you're sitting on, and thus logically self-destructive in the long run, as Thomas More famously asserts in Robert Bolt's play, A Man for All Seasons. More's point, in paraphrase: having torn down the law to get at the "devil” you're after, what will you do if the devil turns on you, all the laws being flat.

This is an admirable and typically liberal sentiment which unfortunately sounds almost quaint in the contemporary context. The critical theorists and activists aren't worried about that since they have abandoned the reciprocity that undergirds the American system altogether. They are playing for power and don't plan on ever not having it again. They've put so many power irons into the fire that it doesn't matter if one or the other fizzles out; they'll have plenty more to brandish.

In a way it's not surprising that it has come to this. The two modes cannot occupy the same ground, it must be all one or all the other, the differences are so glaring. A culture of blameless victims who do not take and are not assigned responsibility for their actions and choices, and are due compensation for their oppression by a perennially culpable majority, cannot function in a representative democracy. The progressive model of human character is too far from the 
self-governing individual under the rule of law applying equally to all on which the Constitution is founded.

Still, we may ask, how could it have come to this, with America being turned into the opposite of itself in a matter of a generation or two.

In an article in National Review in 2012, Andrew McCarthy suggests at least a partial answer. Wondering why, after an "abysmal" first term, President Obama was poised to win re-election, McCarthy argues that the Republicans were simply unable to make a compelling case against the elite leftwing opinion embodied in the administration of the forty-fourth president because, quite simply, "they have accepted the progressive framework."

Allowing for the slightly different preoccupations of nine years ago, his words might appear prophetic:

Their argument is not that the welfare state, deficit spending, federalized education, sharia-democracy promotion, and the rest are bad policies. Their argument is not that Washington needs to be dramatically downsized. It is that progressive governance is fine but needs to be better executed....

Once you abandon these moorings [those supplied by Madison and Hamilton on the limits of the use of federal power], once you accept a wealth-redistribution system in which government becomes the arbiter of "social justice," the ballgame is over. If government is given license to even the scales between the have-nots and the haves, the political incentive to even them will be constant and overpowering: Enough will never be enough.

The "me-too Republican" may have first been birthed during the New Deal. Be that as it may, McCarthy's point perhaps explains why, shortly after the November 2020 election, I heard to my surprise the head of a right wing think tank say to a Zoom meeting that Republicans in D.C. had been telling him how relieved they were that the disruptive Trump was gone, that they could now go back to "business as usual." And he agreed with them.

The good news is that critical race theory has become so blatant and evenshall we say it?-ridiculous, that it has aroused a stunning backlash in many 
venues-on school boards, in corporations, in local governments, among politicians, journalists, employees, teachers, parents, and more. They are writing superb open letters of protest to school administrators, making articulate and impassioned speeches before school panels, withdrawing their children from pricey private schools gone mad over diversity, protesting unequal treatment, even initiating lawsuits regarding specific injustices. In a lecture delivered at Hillsdale College in Michigan, Christopher Rufo describes some of what is happening of a practical nature:

This year, several state legislatures have introduced bills to achieve the . . goal [of] preventing public institutions from conducting programs that stereotype, scapegoat, or demean people on the basis of race. And I have organized a coalition of attorneys to file lawsuits against schools and government agencies that impose critical race theory-based programs on grounds of the First Amendment (which protects citizens from compelled speech), the Fourteenth Amendment (which provides equal protection under the law), and the Civil Rights Act of 1964 (which prohibits public institutions from discriminating on the basis of race).

And now to the issue, our part in the fight. "A nation stays alive when its culture stays alive," nobly reads a sign outside the Afghan National Museum, in English. Into the lists comes every new issue of Academic Questions, offering the sheer mental delight of articles that respect your intellect, based unembarrassedly on reason, logic, evidence, common sense, and a feel for our collective life, as opposed to the idiocy, mendacity, propaganda, and rank nihilism purveyed by the progressive left. Every article, every review, every feature is a slap in the face of the mob, an act of talking back to the racial arsonists, the cultural barbarians, and the hate filled chasm of destruction burning up our culture.

-In “Testing the Tests for Racism," Wilfred Reilly shows what "strict scrutiny" should look like as he examines studies that claim racial discrimination persists in the job market.

-In "Reviving American Higher Education: An Analysis and Blueprint for Action,” Gerson Moreno-Riaño, president of Cornerstone University in Michigan, noting that we are at "the high mark of anti-intellectualism in American higher education," takes on the whole pile of contemporary campus mockeries and suggests ways to dismantle it. 
-John Staddon exposes how social scientists reasoning wrongly come to wrong, if politically convenient, conclusions in “The Devolution of Psychological Science: Memes, Culture, and Systemic Racism.”

-In “Campuses as Faux Nations,” George R. La Noue highlights ways to fight back against the curtailment of rights on college campuses.

-Dan Subotnik talks back to a sensitivity training session in "Fair or Foul in Interracial Discourse."

-In “The New Gilded Age: We've Seen It All Before,” Wight Martindale, Jr. suggests what we can learn about our contemporary situation from The Bostonians, Henry James’s brilliant satire of first wave feminism.

-William L. Krayer coins a word in "Critical Theory vs. 'Mostmodernism”" and debunks more of the "anti-racist" hokum, the idea that innovative research and patent applications are biased.

-In “The Politicization of Education Research and the AERA," Richard Phelps examines an overconfident statement on the scholarship of transgenderism from the American Educational Research Association.

-In "Poisoning the Well of Art Education” Michelle Marder Kamhi keeps hold on the good as she exposes the bad in art education.

-In a review essay, "A Conservative Prof. Sees the Enemy ... And It Is Us!," Seth Forman takes issue with the optimistic pronouncements of one book and cites another for support.

-Steven Kessler warmly remembers Roger Scruton's conservative emphasis on community, past and future, not just on the individual, and not just on the present, in “Sir Roger Scruton: Good, Beautiful, True.” Scruton passed away in 2020.

In Short Takes, Jackson Toby reprises what expansive higher education at its best can do (“An Immigration Story”) and tells why free college can't work (“Free College and the Problem of Readiness"). Dwight D. Murphey uses a medical metaphor to describe the state of things in "Interstitium: The Ideological Domination of America," Daniel Pipes describes "The Wreckage of Endowed Chairs," and John Staddon explains “The Diversity Dilemma.”

Please note the special format for the poetry section in this issue. It looks to our great poetic heritage with poems by John Keats and Charles Baudelaire (the latter in translation), and to the present with a new poem by Catherine Savage Brosman. 